Some by the Way Remarks on Wreen's 'By' Ways

Author(s): Karl Pfeifer

Source: Analysis, Vol. 48, No. 2 (Mar., 1988), pp. 107-109

MODERN MORAL SCEPTICISM

in general; for this will affect which views it is legitimate to describe as forms of moral scepticism - a matter which, it seems to me, is not well understood - which in turn will affect whether or not my conclusion can be generalized. ${ }^{1}$

University of Texas at Arlington, P.O. Box 19527, Arlington, TX 76019, U.S.A.

(C) RICHARD BETT 1988

\title{
REFERENCES
}

[1] Julia Annas, 'Doing Without Objective Values: Ancient and Modern Strategies', in The Norms of Nature, ed. Malcolm Schofield and Gisela Striker, Cambridge University Press, 1986.

[2] Donald Davidson, 'On the Very Idea of a Conceptual Scheme', Proceedings of the American Philosophical Association 47 (1973-4), 5-20.

[3] John McDowell, 'Virtue and Reason', The Monist 62 (1979), 331-50.

[4] Thomas Nagel, The View from Nowhere, Oxford University Press, 1986.

[5] Richard Rorty, Philosophy and the Mirror of Nature, Princeton University Press, 1979.

[6] Richard Rorty, Consequences of Pragmatism, University of Minnesota Press, 1982.

[7] Francis Snare, 'The Empirical Bases of Moral Scepticism', American Philosophical Quarterly 21 (1984), 215-25.

[8] Bernard Williams, Descartes: The Project of Pure Enquiry, Penguin Books, 1978.

${ }^{1}$ I would like to thank Julia Annas for her helpful comments on a previous version of this paper.

\section{SOME BY THE WAY REMARKS ON WREEN'S 'BY' WAYS}

\author{
By Karl Pfeifer
}

MICHAEL Wreen ('Two "By" Ways', Analysis 47.2, March 1987, 1 pp. 120-4) worries about causal loops apparently entailed by some action sentences containing 'by' locutions. These 'paradoxical' loops can be avoided, he contends, by noting that 'by' may indicate either (i) being caused or generated by causal or other sorts of Goldmanian action generation, or (ii) being indirectly achieved or performed by.

This is a specious solution. On the one hand, the kind of loop Wreen has drawn our attention to is inherent in 'by'-locutionary talk generally and not just in the particular kind of causal case he has addressed. On the other hand, the very distinction Wreen seeks to draw is subverted by the fact that indirect performance 
Some by the Way Remarks on Wreen's 'By' Ways

Author(s): Karl Pfeifer

Source: Analysis, Vol. 48, No. 2 (Mar., 1988), pp. 107-109

and achievement are themselves instances of generation on Goldman's account (expounded in A Theory of Human Action, Princeton University Press, 1970; hereafter ' $T H A$ '). And we shall see that Goldman makes a poor ally in any case.

Let me elucidate the problem with a bare bones example. Consider a game, ritual, or whatnot involving the movement of counters of various colours and materials. John moves a black wooden counter, rendering both the following true:

(1) John moves a wooden counter by moving a black counter.

(2) John moves a black counter by moving a wooden counter.

Since the black counter moved is the wooden counter moved, the difference between (1) and (2) seems clearly to be a pragmatic matter of emphasis relative to one's explanatory concerns. And because one can have more than one such concern, one can have it both ways. So the 'by' relation here can be understood as an explanatory relation, sensitive to wording and context, sans paradox. Furthermore the loop in this example can easily be made a matter of indirect performance or achievement.

Suppose John wants to move a black piece because he feels black is lucky. He knows he has to move a wooden counter to do so, since all the black counters of plastic or rubber are gone. To move something black, he must 'overshoot' and move something black-and-wooden. (John is like Wreen's character, Walt, who proves that all natural numbers have property $\mathrm{P}$ by overshooting and proving that all real numbers have property $P$.) Now suppose further that Bill, another participant in this 'counter activity', views the movement of a wooden counter as unlucky and that John recognizes that by moving something black he will perform the from Bill's point of view unlucky act of moving a wooden counter (this would be like Walt's proof, its overshooting aforethought notwithstanding, also amounting to a proof that the naturals have $P$ only if the reals do). Hence we now have a simple indirectperformance-or-achievement loop.

Is there anything wrong with such a loop? No, if one takes the 'by' relation to be explanatory and explainable in ways unfettered by generational presumptions. Yes, if this 'by' relation is construed as Goldman's action generation. That technical transmogrification of a commonplace idiom leads to serious trouble.

Generation is stipulated to be asymmetric, transitive, and irreflexive (THA, p. 21). Moreover it only holds among acts or 'acttokens construed and finely individuated as propertyexemplifications by an agent at a time (THA, p. 10). Yet (1) and (2) above each satisfy Goldman's criterion for the occurrence of the kind of generation he calls 'simple generation'. 'In simple generation', says Goldman, 'the existence of certain circumstances, conjoined with the performance of $A$, ensures that the agent has performed $A^{\prime}$. ' (THA, p. 26) The relevant circumstances in this case 
Some by the Way Remarks on Wreen's 'By' Ways

would include the coincidence of blackness and woodenness in the same counter; this in itself is sufficient to give us the mutual generation of John's act of moving a wooden counter and John's act of moving a black counter. Circumstances for simple generation can also subsume intentions, motives, and beliefs (THA, p. 27), the sorts of things that go into characterizations of 'action plans' (Wreen's phrase). So indirect performance or achievement is in the current context just a special case of simple generation. Such mutual generation - a generational loop - either violates the asymmetry of generation, or, if one countenances the generation of two distinct act-tokens involving the same act-property et seq., violates the identity conditions for act-tokens. Hence examples such as the present one show the generational account to be fundamentally incoherent. ${ }^{1}$

If such a malign loop is to be avoided we must either deny the 'by' relation the offending generational properties, or, failing that, we must give up the idea that particular acts can be straightforwardly identified with exemplifications of act-properties as ascribed by the verb phrases of ordinary action sentences. But if we do that, it is less clear how there was a causal loop problem to begin with.

University of Saskatchewan, Saskatoon, Canada S7NOWO

CC KARL Pfeifer 1988

${ }^{1}$ There are no easy amendments for avoiding this, either. For detailed discussion of this problem see my 'A Problem of Motivation for Multipliers', Southern Journal of Philosophy, 20 (1982) 209-24, and 'A Consideration of Modifications to the Multiplying Account', Philosophy Research Archives, 11 (1985) 141-54.

\section{A REPLY TO CAHN}

\section{By Daniel H. Cohen}

GTEVEN M. CAHN (Analysis 47.3, June 1987, pp. 175-6) asks Show a principled divestiture of stocks is morally possible. The problem, correctly noted, derives from two premises. First, ownership of stock in a company whose policies are morally objectionable is itself morally objectionable. Second, it cannot be morally obligatory to perform an act which requires someone else to commit an offence of identical gravity. Because stocks can only be sold when there is a buyer, selling any such stocks accomplishes no net reduction of morally objectionable economic behaviour in the world. Divestiture, the argument concludes, is something of an 